\title{
Editorial
}

\section{Back to the Future: The End of the Steroid Century?}

Marc A. Huntoon, MD, and Abram H. Burgher, MD

$\mathrm{n}$ this issue of Pain Physician, Manchikanti and colleagues (1-4) report preliminary results of 4 studies designed to assess the benefit of adding corticosteroid to caudal epidural injection of local anesthetic for chronic low back and leg pain. Patients enrolled had one of 4 pain etiologies: discogenic, radicular, postoperative back, or spinal stenosis. In each of the 4 trials, subjects were randomly assigned to a group receiving lidocaine only or another receiving lidocaine plus corticosteroid. The volumes used (10 $\mathrm{mL}$ ) were likely sufficient to fill the caudal space, but small by historical standards (5-8). Manchikanti's group found that on average pain and functional status of patients in all 4 studies improved during 12 months of follow-up after enrollment. Perhaps more importantly, there was no advantage seen with addition of epidural corticosteroid.

The results of these studies cast doubt on the central role that epidural corticosteroid injections have played for more than half a century since the compounds were originally introduced by Hench, Kendall, and others for the treatment of rheumatoid arthritis (9). Prior to Hench et al's work, Evans (7) hypothesized that local anesthetic injected transsacrally might reduce symptoms caused by pressure on nerves. These early injections were high volume caudals, usually of the local anesthetic procaine alone; only later were hydrocortisone acetate or other steroids added (8).

A recent study compared targeted versus non-targeted caudal injections for the treatment of radiculitis. Targeted injections were performed via a caudally introduced endoscope and produced no major improvement in pain intensity versus non-targeted injections during a 6-month follow-up period. Pain, anxiety, and depression all improved in the non-targeted caudal group at the final analysis time of 6 months (10). Another, earlier study by Bush and Hillier (11) was quite small, but demonstrated improvement in the caudal corticosteroid and local anesthetic group relative to saline injection. The volumes used were large $(25 \mathrm{~mL})$ and more similar to historical norms.

Most interventional pain physicians believe that epidural administration of corticosteroids is a useful tool in treating patients with chronic low back and leg pain and, though caudal injections are less widely utilized today, epidural injections using other approaches are more common than ever (12-20). Yet, a synthesis of the current literature would suggest that the benefits of epidural corticosteroids are short-lived, with minimal impact on functional status, reduction in analgesic use, or reduction in surgery incidence in patients with disc herniation. Some guidelines and other publications have questioned the utility of corticosteroids injected epidurally (21-25). One publication suggested too many epidural corticosteroid injections are being performed, with little benefit. "Epidural steroid injections for lumbosacral

From: Mayo Clinic College of Medicine, Rochester, MN.

Dr. Huntoon is Associate Professor Anesthesiology, Department of Anesthesiology, Mayo Clinic College of Medicine, Rochester, MN.

Dr. Burgher is a Fellow with the Department of Anesthesiology, Division of Pain Medicine, Mayo Clinic College of Medicine, Rochester, MN.

Address Correspondence: Marc A. Huntoon, MD Department of Anesthesiology Associate Professor of Anesthesiology Mayo Clinic

Rochester, MN 55905

E-mail: huntoon.marc@mayo.edu 


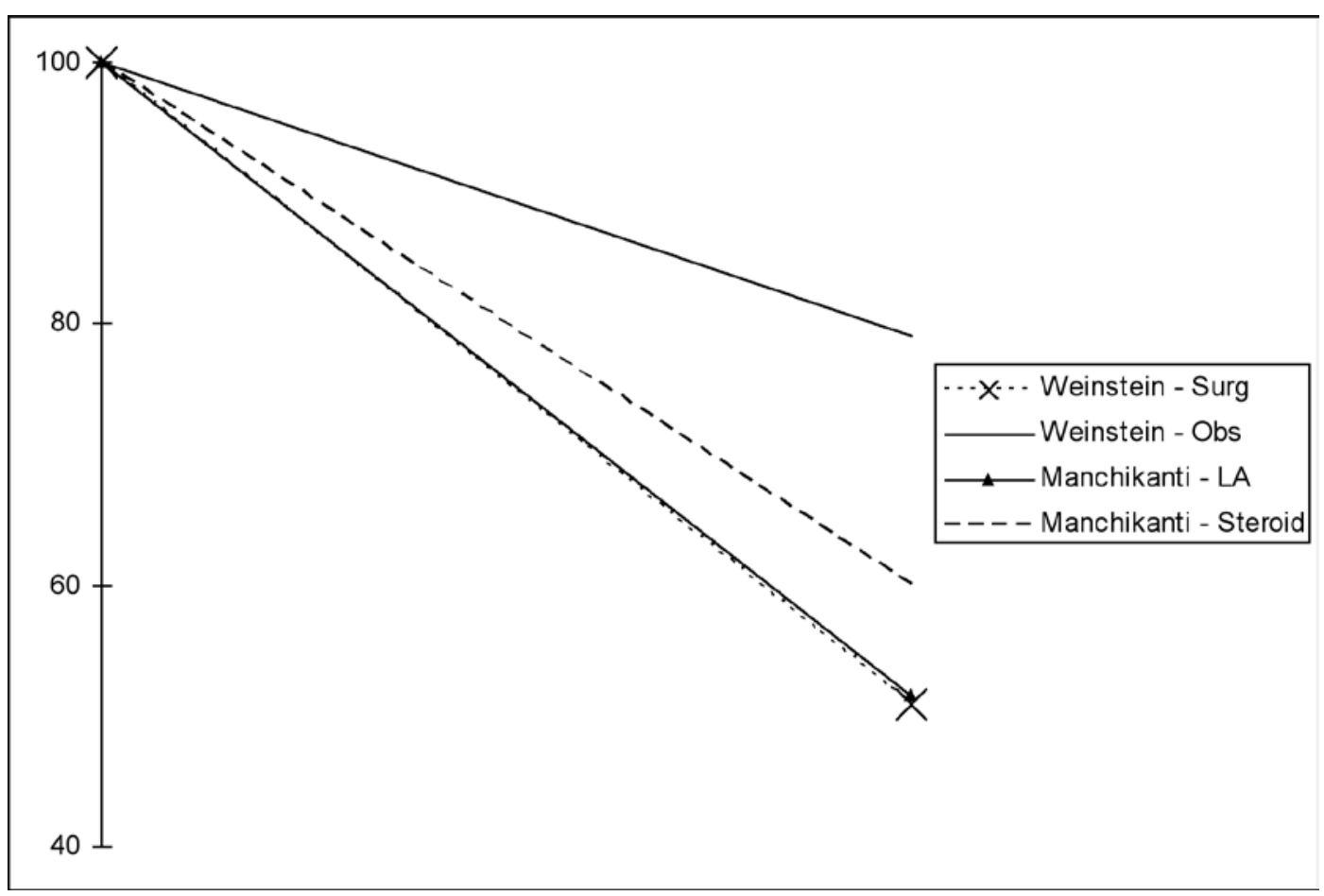

Fig. 1. Mean score in Oswestry Disability Index (ODI) relative to baseline at study enrollment (intersection of y-axis) and at 12 months for 4 patient groups as described in 2 clinical trials. Baseline ODI $=100$ on this scale. Weinstein - Surg = operative arm in Weinstein, et al. 2008; Weinstein - Obs = observational, non-operative arm in Weinstein et al 2008; Manchikanti-LA = local anesthetic only arm of Manchikanti, et al. 2008; Manchikanti - Steroid = local anesthetic plus steroid arm of Manchikanti, et al. 2008.

radicular pain have no impact on average impairment of function, on need for surgery, or on long term pain relief beyond 3 months, and their use for the indications are not recommended" (18).

Few would argue that corticosteroid injections have been associated with a number of complications (26). Complications may include everything from temporary salt and water retention to hyperglycemia, lipid accumulation, osteoporotic vertebral compression fractures, cushingoid features, avascular necrosis of the hip and other joints, immune system deficits, and even death in some cases. Because of the potential risks, many authors advocate limiting the number of epidural corticosteroid injections to 3-4 per year per patient. Currently, attempts are being made to find suitable substitutes for steroids as an adjunct to local anesthetic. There are at least 2 ongoing clinical trials in the United States comparing epidural corticosteroid to an alternative anti-cytokine or neuropathic agent for the treatment of radiculopathy due to herniated disk (see clinicaltrials.gov: http://clinicaltrials.gov/ct2/ show/NCT00588354?term=huntoon\&rank=1; http:// clinicaltrials.gov/ct2/show/NCT00733096?term=cohen $\% 2 \mathrm{C}+$ steven\&rank=6). If the results of these studies are favorable, it may signal a change in the utilization of corticosteroid for chronic back and leg pain syndromes.

So, how do we interpret these new and compelling findings by Manchikanti and his colleagues? If one looks at some of the recent landmark studies comparing operative and non-operative treatment of back and leg pain, there are trends favoring pain and functional improvement in both surgical and non-surgical groups. Using data from the SPORT trial, for example, we can compare Oswestry Disability Index (ODI) scores among patients with lumbar spinal stenosis to ODI in 
Manchikanti's subjects with similar pathology $(1-4,27)$ (Fig. 1). In the Weinstein et al 2008 study (27) patients randomized to and undergoing surgery showed a $49 \%$ improvement in ODI; patients in the observational arm who did not have surgery improved by $21 \%$. Viewed in this light, outcomes seen by Manchikanti et al as published in this issue of Pain Physician, appear favorable - patients showed similar improvement to the Weinstein surgical group in ODI 12 months after enrollment. Those randomized to caudal with local anesthetic had an almost 50\% improvement in ODI, while those receiving corticosteroid had a $40 \%$ improvement. Granted, Manchikanti's patients received multiple procedures during the 1-year follow-up and may have had intervening periods of poor function and worsening pain, for instance just before a repeat caudal epidural injection, whereas Weinstein's patients underwent a single surgical intervention and would be expected to have had a more stable course after initial postoperative convalescence. Still, a caudal injection is much less invasive than lumbar spine surgery.

There is no doubt that the natural history of back and radicular pain is to improve over time, and the impact of expected symptomatic improvement cannot be accounted for in any of the Manchikanti et al (14) manuscripts. To know the effect of local anesthetic caudal injection with or without steroid relative to the natural history in this group of patients, one would have to perform a true randomized, placebo-controlled trial with sham injection. Nevertheless, given the low risk of caudal injection, one could argue that it is reasonable to offer this therapy to patients in the absence of firmer evidence. Certainly, a trial of this in- tervention could be performed prior to surgery. The Manchikanti et al data support this approach, since patients in all 4 studies could be divided into "successful" and "failed" groups after 2 injections (1-4).

If we assume that the results of Manchikanti et al do in fact support the use of local anesthetic only caudal injections, we must ask ourselves, "What is the mechanism?" Many patients seemed to show improvement which outlasted the expected duration of local anesthetic - by weeks or months. Is it possible that local anesthetic alone had an effect in modulating the neurobiological maintenance of many pain syndromes, and the effects may persist beyond the known pharmacologic duration of local anesthetic? As eluded in Manchikanti et al's manuscripts (1-4) and other controlled studies (28-30), the evidence shows that long-lasting effect may be obtained with local anesthetics with or without steroids. Further, Tachihara et al (31) presented experimental evidence in rats that nerve root infiltration prevented mechanical allodynia; however, no additional benefit from using corticosteroid was identified, suggesting that corticosteroid may be unnecessary for nerve root blocks. Even then, the protracted effect of local anesthetic administered caudally in the Manchikanti articles is difficult to understand. Further study of caudal injection of local anesthetic is necessary to better explain the mechanisms involved in the treatment of these pain syndromes. But for the time being, outcomes from the Manchikanti studies suggest we should suspend disbelief and return to an earlier time. In the 1930s, they were doing caudal epidurals with local anesthetic only

\section{References}

1.. Manchikanti L, Cash KA, McManus CD, Pampati V. Smith HS. Preliminary results of randomized equivalence trial of fluoroscopic caudal epidural injections in managing chronic low back pain: Part 1. Discogenic pain without disc herniation or radiculitis. Pain Physician 2008; 11:785-800.

2. Manchikanti L, Singh V, Cash KA, , Pampati V, Damron KS, Boswell MV. Preliminary results of randomized equivalence trial of fluoroscopic caudal epidural injections in managing chronic low back pain: Part 2. Disc herniation and radiculitis. Pain Physician 2008; 11:801-815.
3. Manchikanti L, Singh VJ, Cash KA, Pampati V. Datta S. Preliminary results of randomized equivalence trial of fluoroscopic caudal epidural injections in managing chronic low back pain: Part 3. Post-surgical syndrome. Pain Physician 2008; 11:817-831.

4. Manchikanti L, Cash KA, McManus CD, Pampati V. Abdi S. Preliminary results of randomized equivalence trial of fluoroscopic caudal epidural injections in managing chronic low back pain: Part 4. Spinal Stenosis. Pain Physician 2008; 11:833-848.
5. Manchikanti L, Bakhit CE, Pampati V. The role of epidurography in caudal neuroplasty. Pain Digest 1998; 8:277281.

6. Manchikanti L, Cash KA, Pampati V, McManus CD, Damron KS. Evaluation of fluoroscopically guided caudal epidural injections. Pain Physician 2004; 7:8192.

7. Evans W. Intrasacral epidural injection in the treatment of sciatica. Lancet 1930; Dec 6:1225-1229.

8. Goebert HW Jr, Jallo SJ, Gardner WJ, Wasmuth CE. Painful radiculopathy 
treated with epidural injections of procaine and hydrocortisone acetate: Result in 113 patients. Anesth Analg 1961; 140:130-134.

9. Hench PS, Kendal EC, Slocumb CH, et al. The effect of a hormone of the adrenal cortex (17-hydroxy-11-dehydrocorticosterone: Compound E) and of pituitary adrenocorticotropic hormone on rheumatoid arthritis. Proc Staff Mayo Clin 1949; 24:181-197.

10. Dashfield AK, Taylor MB, Cleaver JS, Farrow D. Comparison of caudal epidural steroid with targeted steroid placement during spinal endoscopy for chronic sciatica: A prospective randomized, double-blind trial. Br J Anaesth 2005; 94:514-519.

11. Bush K, Hillier S. A controlled study of caudal epidural injections of triamcinolone plus procaine for the management of intractable scatica. Spine 1991; 15:572-575.

12. Manchikanti L. The growth of interventional pain management in the new millennium: A critical analysis of utilization in the Medicare population. Pain Physician 2004; 7:465-482.

13. Manchikanti L, Giordano J. Physician payment 2008 for interventionalists: Current state of health care policy. Pain Physician 2007; 10:607-626.

14. Friedly J, Leighton C, Deyo R. Increases in lumbosacral injections in the Medicare population: 1994 to 2001. Spine 2007; 32:1754-1760.

15. Friedly J, Nishio I, Bishop MJ, Maynard C. The relationship between repeated epidural steroid injections and subsequent opioid use and lumbar surgery. Arch Phys Med Rehabil 2008; 89:10111015.

16. Specialty Utilization data files from CMS: www.cms.hhs.gov/physicians/ pfs/

17. Abdi S, Datta S, Trescot AM, Schultz DM, Adlaka R, Atluri SL, Smith HS, Manchikanti L. Epidural steroids in the management of chronic spinal pain: A systematic review. Pain Physician 2007; 10:185-212.

18. Armon C, Argoff CE, Samuels J, Backonja M-M. Assessment: Use of epidu- ral steroid injections to treat radicular lumbosacral pain: Report of the Therapeutics and Technology Assessment Subcommittee of the American Academy of Neurology. Neurology 2007;6 8:723-729.

19. Staal JB, de Bie R, de Vet HC, Hildebrandt J, Nelemans P. Injection therapy for subacute and chronic low-back pain. Cochrane Database Syst Rev 2008; 3:CD001824.

20. Boswell MV, Trescot AM, Datta S, Schultz DM, Hansen HC, Abdi S, Sehgal N, Shah RV, Singh V, Benyamin RM, Patel VB, Buenaventura RM, Colson JD, Cordner HJ, Epter RS, Jasper JF, Dunbar EE, Atluri SL, Bowman RC, Deer TR, Swicegood JR, Staats PS, Smith HS, Burton AW, Kloth DS, Giordano J, Manchikanti L. Interventional techniques: Evidencebased practice guidelines in the management of chronic spinal pain. Pain Physician 2007; 10:7-111.

21. American College of Occupational and Environmental Medicine (ACOEM) Low back Disorders. In: Occupational Medicine Practice Guidelines: Evaluation and Management of Common Health Problems and Functional Recovery of Workers, Second Edition. American College of Occupational and Environmental Medicine, Elk Grove Village, 2007.

22. American College of Occupational and Environmental Medicine. Chronic Pain Chapter (revised 2008). In: Occupational Medicine Practice Guidelines: Evaluation and Management of Common Health Problems and Functional Recovery of Workers, Second Edition. American College of Occupational and Environmental Medicine, Elk Grove Village, Epublished August 14, 2008.

23. Manchikanti L, Singh V, Derby R, Helm S, Trescot AM, Staats PS, Prager JP, Hirsch JA. Review of occupational medicine practice guidelines for interventional pain management and potential implications. Pain Physician 2008; 11:271-289.

24. Manchikanti L, Singh V, Helm S, Trescot AM, Hirsch JA. A critical appraisal of 2007 American College of Occupational and Environmental Medicine (ACO-
EM) practice guidelines for interventional pain management: An independent review utilizing AGREE, AMA, IOM, and other criteria. Pain Physician 2008; 11:291-310.

25. Manchikanti L, Singh V, Derby R, Schultz DM, Benyamin RM, Prager JP, Hirsch JA. Reassessment of evidence synthesis of occupational medicine practice guidelines for interventional pain management. Pain Physician 2008; 11:393482.

26. Huntoon MA. Complications Associated with Chronic Steroid Use. In: Neal JM, Rathmell JP. Complications in Regional Anesthesia and Pain Medicine, WB Saunders Philadelphia, 2006 pp.331-339.

27. Weinstein JN, Tosteson TD, Lurie JD, Tosteson AN, Blood E, Hanscom B, Herkowitz H, Cammisa F, Albert T, Boden SD, Hilibrand A, Goldberg H, Berven S, An H; SPORT Investigators. Surgical versus nonsurgical therapy for lumbar spinal stenosis. NEJM 2008; 358:794-810.

28. Manchikanti L, Singh V, Falco FJE, Cash KA, Pampati V. Lumbar facet joint nerve blocks in managing chronic facet joint pain: One-year follow-up of a randomized, double-blind controlled trial: Clinical Trial NCToo355914. Pain Physician 2008; 11:121-132.

29. Manchikanti L, Singh V, Falco FJ, Cash KM, Fellows B. Cervical medial branch blocks for chronic cervical facet joint pain: A randomized, double-blind, controlled trial with 1-year follow-up. Spine 2008; 33:1813-1820.

30. Manchikanti L, Singh V, Falco FJ, Cash KM, Pampati V. Effectiveness of thoracic medial branch blocks in managing chronic pain: A preliminary report of a randomized, double-blind controlled trial: Clinical Trial NCTo0355706. Pain Physician 2008; 11:491-504.

31. Tachihara H, Sekiguchi M, Kikuchi S, Konno S. Do corticosteroids produce additional benefit in nerve root infiltration for lumbar disc herniation. Spine 2008; 33:743-747. 